\title{
HUBUNGAN ANTARA KEPRIBADIAN DASAR DAN KAPASITAS MENTAL DENGAN PERSEPSI, PERILAKU DAN INTENSI INTEGRITAS AKADEMIK
}

\author{
Hikmah Muktamiroh*, Yayi Suryo Prabandari**, Soenarto Sastrowijoto*** \\ * Fakultas Kedokteran Universitas Pembangunan Nasional “Veteran” Jakarta \\ ** Bagian Pendidikan Kedokteran, Fakultas Kedokteran, Universitas Gadjah Mada \\ *** Center for Bioethics and Medical Humanities, Fakultas Kedokteran, Universitas Gadjah Mada
}

\begin{abstract}
Background: Educational institutions must promote the learning of professional behavior as early as possible and conduct evaluation of the implementation, including evaluation of the academic integrity implementation. This study aims to determine the academic integrity perception, behavior and intention of students and their relation to mental capacity and basic personality of students based on the MMPI-2 measurements.

Method: This was a non-experimental, conducting quantitative survey involving 209 medical students from one of Faculty of Medicine in Indonesia.

Results: The relationship between mental capacity and basic personality based on the measurement of MMPI-2 and the perceptions, attitude and intentions of academic integrity were found. On mental capacity, a correlation was found between potential performance and perceptions $(r=0.169$ and $p=0.014)$ and academic integrity behavior $(r=0.170$ and $p=0.014)$, between adaptability and perception of academic integrity of fellow students $(r=0.149$ and $p=0.032)$, between psychological constraints and academic integrity behavior score $(r=0.137$ and $p=0.049)$ and between moral integrity and perception score of academic integrity $(r=-0.220$ and $p=0.001)$. On the basic personality, there was a correlation between openness to pressure and perceptions of academic integrity of fellow students $(r=0.141$ and $p=0.041)$, as well as between basic personality and perception $(r=0.169$ and $p=0.014)$ and academic integrity behavior $(r=0.154$ and $p=0.026$ ).
\end{abstract}

Conclusion: There is a correlation in some variables of mental capacity and basic personality based on MMPI-2 to perception and academic integrity behavior.

Keywords: professional behavior, academic integrity, mental capacity, basic personality

\section{ABSTRAK}

Latar belakang: Institusi pendidikan harus memberikan pembelajaran perilaku profesional (professional behaviour) sejak dini dan melakukan evaluasi implementasinya, termasuk evaluasi implementasi integritas akademik. Penelitian ini bertujuan untuk mengetahui persepsi, perilaku dan intensi integritas akademik mahasiswa serta hubungannya dengan kapasitas mental dan kepribadian dasar mahasiswa berdasar pengukuran MMPI-2.

Metode: Penelitian ini merupakan survei kuantitatif non eksperimental melibatkan 209 mahasiswa kedokteran dari salah satu fakultas kedokteran di Indonesia.

Hasil: Mengetahui hubungan antara kapasitas mental dan kepribadian dasar berdasar pengukuran MMPI-2 dengan persepsi, perilaku dan intensi integritas akademik. Pada kapasitas mental, ditemukan hubungan korelasi antara potensi kinerja dengan persepsi $(r=0,169$ dan $p=0,014)$ dan perilaku $(r=0,170$ dan $p=0,014)$ integritas akademik, antara kemampuan adaptasi dengan persepsi terhadap integritas akademik teman sesama mahasiswa $(\mathrm{r}=0,149$ dan $\mathrm{p}=0,032)$, antara kendala psikologis dengan skor perilaku integritas akademik $(\mathrm{r}$ $=0,137$ dan $p=0,049)$ dan antara integritas moral dengan skor persepsi integritas akademik $(r=-0,220$

korespondensi: hikmah.oar@gmail.com 
dan $\mathrm{p}=0,001)$. Pada kepribadian dasar, ditemukan hubungan korelasi antara keterbukaan tekanan dengan persepsi terhadap integritas akademik teman sesama mahasiswa $(r=0,141$ dan $p=0,041)$, serta kepribadian dasar dengan persepsi $(r=0,169$ dan $p=0,014)$ dan perilaku $(r=0,154$ dan $p=0,026)$ integritas akademik. Kesimpulan: Terdapat korelasi pada beberapa variabel kapasitas mental dan kepribadian dasar dengan persepsi dan perilaku integritas akademik.

Kata kunci: perilaku profesional, integritas akademik, kapasitas mental, kepribadian dasar

\section{PENDAHULUAN}

Institusi pendidikan harus menanamkan pembelajaran perilaku profesional sejak dini dan melakukan evaluasi implementasinya, termasuk evaluasi implementasi integritas akademik. Suatu terobosan harus dilakukan, karena membentuk mahasiswa menjadi lulusan yang profesional bukanlah hal yang mudah dan tidak dapat dicapai dalam waktu singkat. Bila mengingat mahasiswa kedokteran harus memiliki knowledge, skills dan attitude maka selayaknyalah seleksi mahasiswa juga harus mempertimbangkan knowledge, skills dan attitude.

Passi et al. ${ }^{1}$ menyatakan bahwa berdasar literature review, terdapat 5 aspek yang perlu diperhatikan untuk mengembangkan profesionalisme pada mahasiswa, yaitu desain kurikulum, seleksi mahasiswa, metode belajar mengajar, role model dan metode assessment. Petersdorf dan Swick menyatakan bahwa seharusnya pendidikan dokter harus mempersiapkan mahasiswa untuk menjadi seorang praktisi dengan pengembangan pengetahuan dan keterampilan praktis serta standar etika dan moral yang tinggi termasuk integritas. ${ }^{2,3}$ Van Luijk menambahkan bahwa sikap dan perilaku etik merupakan bagian dari profesionalisme. ${ }^{4}$ Beberapa perilaku yang diharapkan muncul dari seorang mahasiswa kedokteran adalah honesty, respect, fairness, responsibility, trust. ${ }^{5}$ Perilaku tersebut sesuai dengan perilaku yang diharapkan oleh The Center of Academic Integrity yang mendefinisikan integritas akademik sebagai komitmen (bahkan saat menghadapi kesulitan) atas 5 nilai dasar: kejujuran, kepercayaan, keadilan, menghormati dan tanggung jawab.

Saat ini, beberapa fakultas kedokteran di Indonesia menggunakan MMPI sebagai salah satu komponen seleksi penerimaan mahasiswa baru. MMPI (Minessota Multiphasic Personality Inventory) merupakan salah satu bentuk tes psikologik yang disusun sedemikian rupa, sehingga merupakan instrumen yang secara akurat dapat memberikan gambaran kecenderungan kepribadian tertentu. MMPI memiliki variabel kapasitas mental dan kepribadian dasar. Kapasitas mental memilikivariabel potensi kinerja, kemampuan adaptasi, kendala psikologis, perilaku berisiko dan integritas moral. Sedangkan kepribadian dasar memiliki variabel keterbukaan pikiran, keterbukaan hati, keterbukaan terhadap orang lain, keterbukaan terhadap kesepakatan dan keterbukaan terhadap tekanan. ${ }^{7}$

Peneliti ingin mengetahui hubungan persepsi, perilaku dan intensi integritas akademik mahasiswa dengan kapasitas mental dan kepribadian dasar mahasiswa berdasar pengukuran MMPI-2.

\section{METODE}

Penelitian ini merupakan penelitian survei kuantitatif non eksperimental yang dilakukan pada satu fakultas kedokteran di Indonesia pada Juni November 2011. Populasi adalah 209 mahasiswa dari mahasiswa tingkat 1,2 dan 3 .

Alat yang digunakan untuk meneliti integritas akademik adalah kuesioner integritas akademik dari Roff ${ }^{8}$ yang sebelumnya telah mengalami uji validitas dan reliabilitas. Untuk meneliti kapasitas mental dan kepribadian dasar, alat yang digunakan adalah MMPI-2. MMPI-2 telah diuji validitasnya oleh Indonesian Center for Mental Health Training and Research pada tahun 2003 dan telah digunakan secara luas oleh para psikiater di Indonesia. Kapasitas mental dan kepribadian dasar berdasar pengukuran 
MMPI-2 yang digunakan dalam penelitian ini telah dikonsultasikan pada psikiater yang berkompeten.

Kriteria inklusi pada penelitian ini adalah tercatat sebagai mahasiswa aktif fakultas kedokteran, berusia 18 tahun atau lebih saat MMPI-2 dilakukan dan bersedia menjadi responden. Kriteria usia 18 tahun didasarkan pada pernyataan Butcher et al. yang menyatakan bahwa MMPI-2 tidak dianjurkan penggunaannya untuk usia di bawah 18 tahun. $^{9}$ Kriteria eksklusi, adalah: 1) Kuesioner integritas akademik tidak terisi lengkap dan atau; 2) Data MMPI-2 tidak ada/tidak dapat dianalisis dan atau; 3) Mengundurkan diri dari penelitian.

Penelitian mendapatkan persetujuan mahasiswa melalui informed consent yang dilakukan sebelum pengambilan data dengan kuesioner serta telah mendapatkan persetujuan (ethical clearance) dari Komite Etik Fakultas Kedokteran dan Kesehatan FK UGM.

\section{HASIL DAN PEMBAHASAN}

\section{Hasil pengukuran kapasitas mental dan kepribadi- an dasar berdasar MMPI-2}

Penelitian menunjukkan bahwa berdasar pengukuran MMPI-2, potensi kinerja kurang (78,5\%), kemampuan adaptasi sedang $(67,5 \%)$, kendala psikologis sedang $(71,3 \%)$, perilaku berisiko sedang $(75,1 \%)$ dan integritas moral sedang (76,1\%) mendominasi distribusi tiap variabel kapasitas mental. Perbandingan persentase mahasiswa dengan kapasitas mental baik (26,8\%) dan sangat baik $(1,0 \%)$ masih sedikit lebih tinggi dibandingkan dengan buruk (21,1\%) dan sangat buruk $(0,5 \%)$. Akan tetapi, beberapa hal yang perlu diperhatikan adalah: 1) kapasitas mental buruk dan sangat buruk hampir mencapai seperempat responden; 2) persentase potensi kinerja kurang mencapai $78,5 \%$; 3) persentase perilaku berisiko besar mencapai $18,7 \%$, dan integritas moral rendah $17,2 \%$.

Berdasar hasil pengukuran MMPI-2 ditemukan bahwa keterbukaan pikiran sedang $(53,1 \%)$, keterbukaan hati besar $(53,1 \%)$, keterbukaan terhadap orang lain sedang $(63,6 \%)$, keterbukaan terhadap kesepakatan sedang $(63,6 \%)$ dan keterbukaan terhadap tekanan sedang $(56,0 \%)$ mendominasi distribusi tiap variabel pengukuran kepribadian dasar berdasar MMPI-2 pada responden. Perbandingan persentase mahasiswa dengan kepribadian dasar baik $(30,6 \%)$ dan sangat baik $(2,4 \%)$ masih sedikit lebih tinggi dibandingkan dengan buruk $(25,4 \%)$ dan sangat buruk $(2,4 \%)$. Akan tetapi, beberapa hal yang perlu diperhatikan adalah: 1) kepribadian dasar buruk dan sangat buruk mencapai lebih dari seperempat responden; 2) persentase keterbukaan pikiran kurang mencapai hampir separuh jumlah responden $(55,5 \%) ; 3)$ persentase keterbukaan terhadap tekanan kurang mencapai hampir 40\% (36,8\%) dan 4) keterbukaan terhadap kesepakatan kurang 20,1\%.

Selanjutnya, berdasar uji korelasi koefisien kontingensi, secara statistik terdapat korelasi yang lemah antara jenis kelamin dengan integritas moral $(\mathrm{p}=$ 0,009 dan $r=0,208$ ) dan tidak didapatkan adanya korelasi antara jenis kelamin dengan potensi kinerja, kemampuan adaptasi, kendala psikologis, perilaku berisiko maupun indeks kapasitas mental mahasiswa, keterbukaan pikiran, keterbukaan hati, keterbukaan terhadap orang lain, keterbukaan terhadap kesepakatan, keterbukaan terhadap tekanan maupun indeks kepribadian mahasiswa.

Berdasar uji korelasi gamma, secara statistik terdapat korelasi yang lemah antara tingkat pendidikan mahasiswa dengan potensi kinerja berdasar MMPI-2 $(\mathrm{p}=0,038$ dan $\mathrm{r}=0,281)$, antara tingkat pendidikan ibu dengan integritas moral $(p=0,036$ dan $r=0,285)$, serta antara tingkat pendidikan mahasiswa dengan keterbukaan pikiran $(\mathrm{p}=0,008$ dan $\mathrm{r}=0,285)$. Tidak didapatkan adanya korelasi antara: 1) umur dengan potensi kinerja, kemampuan adaptasi, kendala psikologis, perilaku berisiko, integritas moral, indeks kapasitas mental mahasiswa, keterbukaan pikiran, keterbukaan hati, keterbukaan terhadap orang lain, keterbukaan terhadap kesepakatan, keterbukaan terhadap tekanan maupun indeks kepribadian dasar mahasiswa; 2) tingkat pendidikan mahasiswa dengan kemampuan adaptasi, kendala psikologis, perilaku berisiko, integritas moral maupun indeks kapasitas mental mahasiswa, keterbukaan hati, keterbukaan terhadap orang lain, keterbukaan terhadap kesepakatan, keterbukaan terhadap tekanan maupun 
indeks kepribadian dasar mahasiswa; 3) tingkat pendidikan ibu dengan potensi kinerja, kemampuan adaptasi, kendala psikologis, perilaku berisiko, maupun indeks kapasitas mental mahasiswa, keterbukaan pikiran, keterbukaan hati, keterbukaan terhadap orang lain, keterbukaan terhadap kesepakatan, keterbukaan terhadap tekanan maupun indeks kepribadian dasar mahasiswa; 4) tingkat pendidikan ayah dengan potensi kinerja, kemampuan adaptasi, kendala psikologis, perilaku berisiko, integritas moral maupun indeks kapasitas mental mahasiswa, keterbukaan pikiran, keterbukaan hati, keterbukaan terhadap orang lain, keterbukaan terhadap kesepakatan, keterbukaan terhadap tekanan maupun indeks kepribadian dasar mahasiswa.

\section{Hubungan kapasitas mental dan kepribadian dasar} berdasar MMPI-2 dengan integritas akademik

Gambaran skor integritas akademik ditunjukkan pada Tabel 1, sedangkan korelasi kapasitas mental dan kepribadian dasar dengan integritas akademik ditunjukkan pada Tabel 2 dan Tabel 3.

Tabel 1. Skor Integritas Akademik pada Mahasiswa Fakultas Kedokteran

\begin{tabular}{llrc}
\multicolumn{1}{c}{ Kategori } & & \multicolumn{2}{c}{ Frekuensi } \\
& & N & $\%$ \\
\multirow{2}{*}{ Skor persepsi integritas akademik } & Kurang & 25 & 12,0 \\
& Sedang & 152 & 72,7 \\
& Baik & 32 & 15,3 \\
\hline \multirow{2}{*}{ Skor persepsi terhadap integritas akademik } & Kurang & 26 & 12,4 \\
teman sesama mahasiswa & Sedang & 150 & 71,7 \\
& Baik & 33 & 15,8 \\
\hline \multirow{2}{*}{ Skor persepsi terhadap sanksi pelanggaran } & Kurang & 36 & 17,2 \\
integritas akademik yang pertama kali & Sedang & 145 & 69,4 \\
& Baik & 28 & 13,4 \\
\hline \multirow{2}{*}{ Skor perilaku integritas akademik } & Kurang & 34 & 16,3 \\
& Sedang & 135 & 64,6 \\
& Baik & 40 & 19,2 \\
\hline \multirow{2}{*}{ Skor intensi pelanggaran integritas akademik } & Kurang & 32 & 15,3 \\
& Sedang & 154 & 73,7 \\
& Baik & 23 & 11,0 \\
\hline
\end{tabular}

Selanjutnya, berdasar uji korelasi contingency coefficient secara statistik didapatkan adanya korelasi sangat lemah antara jenis kelamin mahasiswa dengan skor persepsi integritas akademik $(p=0,017$ dan $r=$ 0,194). Tidak didapatkan adanya korelasi antara jenis kelamin mahasiswa dengan skor persepsi terhadap integritas akademik teman sesama mahasiswa, skor persepsi terhadap sanksi pelanggaran integritas akademik yang pertama, skor perilaku integritas akademik dan skor intensi pelanggaran integritas akademik.
Berdasar uji korelasi Somers'd, secara statistik tidak didapatkan adanya korelasi antara umur, tingkat pendidikan ibu dan tingkat pendidikan ayah dengan skor persepsi integritas akademik, skor persepsi terhadap integritas akademik teman sesama mahasiswa, skor persepsi terhadap sanksi pelanggaran integritas akademik yang pertama, skor perilaku integritas akademik dan skor intensi pelanggaran integritas akademik. Secara statistik ditemukan korelasi yang sangat lemah dengan arah korelasi negatif antara tingkat pendidikan dengan skor persepsi integritas akademik $(p=0,007$ dan $r$ 
Tabel 2. Hasil uji korelasi Spearman rank kapasitas mental dengan skor integritas akademik

\begin{tabular}{|c|c|c|c|c|c|c|}
\hline & & $\begin{array}{c}\text { Skor } \\
\text { persepsi } \\
\text { integritas } \\
\text { akademik }\end{array}$ & $\begin{array}{l}\text { Skor persepsi } \\
\text { terhadap integritas } \\
\text { akademik teman } \\
\text { sesama mahasiswa }\end{array}$ & $\begin{array}{l}\text { Skor persepsi } \\
\text { terhadap sanksi } \\
\text { pelanggaran } \\
\text { integritas kademik } \\
\text { yang pertama }\end{array}$ & $\begin{array}{l}\text { Skor perilaku } \\
\text { integritas } \\
\text { akademik }\end{array}$ & $\begin{array}{c}\text { Skor intensi } \\
\text { integritas } \\
\text { akademik }\end{array}$ \\
\hline \multirow{3}{*}{ Potensi kinerja } & $r$ & $0,169^{*}$ & 0,122 & $-0,132$ & $0,170^{*}$ & 0,096 \\
\hline & $p$ & 0,014 & 0,078 & 0,056 & 0,014 & 0,166 \\
\hline & $\mathrm{N}$ & 209 & 209 & 209 & 209 & 209 \\
\hline \multirow{3}{*}{$\begin{array}{l}\text { Kemampuan } \\
\text { adaptasi }\end{array}$} & $r$ & $-0,006$ & $0,149^{*}$ & $-0,062$ & $-0,009$ & 0,019 \\
\hline & $p$ & 0,931 & 0,032 & 0,370 & 0,900 & 0,783 \\
\hline & $N$ & 209 & 209 & 209 & 209 & 209 \\
\hline \multirow{3}{*}{ Kendala psikologis } & $r$ & 0,108 & 0,106 & $-0,008$ & $0,137^{*}$ & 0,075 \\
\hline & $p$ & 0,119 & 0,128 & 0,911 & 0,049 & 0,280 \\
\hline & $N$ & 209 & 209 & 209 & 209 & 209 \\
\hline \multirow{3}{*}{ Perilaku berisiko } & $r$ & 0,052 & 0,021 & 0,005 & 0,133 & 0,080 \\
\hline & $p$ & 0,456 & 0,763 & 0,941 & 0,054 & 0,248 \\
\hline & $\mathrm{N}$ & 209 & 209 & 209 & 209 & 209 \\
\hline \multirow{3}{*}{ Integritas moral } & $r$ & $-0,220^{* *}$ & $-0,082$ & 0,056 & $-0,043$ & $-0,021$ \\
\hline & $p$ & 0,001 & 0,238 & 0,417 & 0,533 & 0,766 \\
\hline & $N$ & 209 & 209 & 209 & 209 & 209 \\
\hline \multirow{3}{*}{ Kapasitas mental } & $r$ & 0,062 & 0,041 & 0,009 & 0,112 & 0,079 \\
\hline & $p$ & 0,370 & 0,557 & 0,897 & 0,105 & 0,255 \\
\hline & $N$ & 209 & 209 & 209 & 209 & 209 \\
\hline
\end{tabular}

* = korelasi sangat lemah, arah korelasi positif; $\quad$ ** = korelasi lemah, arah korelasi negatif

$=-0,135)$, dan skor intensi pelanggaran integritas akademik $(\mathrm{p}=0,048$ dan $\mathrm{r}=-0,097)$; tetapi tidak didapatkan adanya korelasi antara tingkat pendidikan dengan skor persepsi terhadap integritas akademik teman sesama mahasiswa, skor persepsi terhadap sanksi pelanggaran integritas akademik yang pertama, dan skor perilaku integritas akademik.

Skala dalam MMPI merupakan proyeksi dari kecenderungan individu dalam menghadapi aspekaspek tertentu dalam kehidupan pribadi. $^{10}$ Pada penelitian ini, aspek tertentu yang diamati adalah integritas akademik. Dengan komposisi kapasitas mental dan kepribadian dasar berdasar pengukuran MMPI-2 seperti tersebut di atas, diharapkan mahasiswa memiliki kecenderungan individu saat menghadapi aspek-aspek kehidupan pribadi tertentu (dalam hal ini tantangan dan tuntutan integritas akademik) yang cukup baik pula. Diharapkan juga, integritas akademik mahasiswa yang baik sedikit lebih tinggi dibandingkan dengan yang buruk. Berdasar penelitian, ditemukan bahwa skor perilaku integritas akademik didominasi oleh skor kategori sedang $(64,6 \%)$ dan persentase skor perilaku integritas akademik baik $(19,2 \%)$ lebih tinggi dibandingkan dengan persentase skor perilaku integritas akademik kurang (16,3\%).

Uji statistik menunjukkan bahwa tidak terdapat korelasi antara kapasitas mental berdasar pengukuran MMPI-2 dengan skor persepsi, skor persepsi terhadap integritas akademik teman, skor persepsi terhadap sanksi pelanggaran integritas akademik, skor perilaku integritas akademik dan skor intensi integritas akademik. Hal ini kemungkinan berkaitan dengan banyaknya variabel pada kapasitas mental berdasar pengukuran MMPI-2. Melalui uji statistik, terbukti bahwa terdapat korelasi sangat lemah 
Tabel 3. Hasil Uji Korelasi Spearman Rank Kepribadian Dasar dengan Integritas Akademik

\begin{tabular}{|c|c|c|c|c|c|c|}
\hline & & $\begin{array}{c}\text { Skor persepsi } \\
\text { integritas } \\
\text { akademik }\end{array}$ & $\begin{array}{l}\text { Skor persepsi } \\
\text { terhadap integritas } \\
\text { akademik } \\
\text { teman sesama } \\
\text { mahasiswa }\end{array}$ & $\begin{array}{l}\text { Skor persepsi } \\
\text { terhadap sanksi } \\
\text { pelanggaran } \\
\text { integritas } \\
\text { akademik } \\
\text { yang pertam }\end{array}$ & $\begin{array}{c}\text { Skor perilaku } \\
\text { integritas } \\
\text { akademik }\end{array}$ & $\begin{array}{l}\text { Skor intensi } \\
\text { integritas } \\
\text { akademik }\end{array}$ \\
\hline \multirow{3}{*}{$\begin{array}{l}\text { Keterbukaan } \\
\text { pikiran }\end{array}$} & $\mathrm{r}$ & $-0,033$ & 0,100 & 0,007 & 0,028 & 0,049 \\
\hline & $\mathrm{p}$ & 0,637 & 0,149 & 0,924 & 0,691 & 0,484 \\
\hline & $\mathrm{N}$ & 209 & 209 & 209 & 209 & 209 \\
\hline \multirow{3}{*}{ Keterbukaan hati } & $\mathrm{r}$ & 0,041 & 0,022 & 0,027 & 0,52 & 0,092 \\
\hline & $\mathrm{p}$ & 0,552 & 0,753 & 0,699 & 0,454 & 0,185 \\
\hline & $\mathrm{N}$ & 209 & 209 & 209 & 209 & 209 \\
\hline \multirow{3}{*}{$\begin{array}{l}\text { Keterbukaan } \\
\text { terhadap orang } \\
\text { lain }\end{array}$} & $\mathrm{r}$ & 0,115 & 0,008 & $-0,002$ & 0,078 & 0,029 \\
\hline & $\mathrm{p}$ & 0,097 & 0,904 & 0,981 & 0,263 & 0,673 \\
\hline & $\mathrm{N}$ & 209 & 209 & 209 & 209 & 209 \\
\hline \multirow{3}{*}{$\begin{array}{l}\text { Keterbukaan } \\
\text { terhadap } \\
\text { kesepakatan }\end{array}$} & $\mathrm{r}$ & 0,022 & 0,063 & $-0,007$ & 0,045 & $-0,006$ \\
\hline & $\mathrm{p}$ & 0,756 & 0,366 & 0,915 & 0,522 & 0,934 \\
\hline & $\mathrm{N}$ & 209 & 209 & 209 & 209 & 209 \\
\hline \multirow{3}{*}{$\begin{array}{l}\text { Keterbukaan } \\
\text { terhadap tekanan }\end{array}$} & $\mathrm{r}$ & 0,066 & $0,141^{*}$ & $-0,044$ & 0,118 & 0,071 \\
\hline & $\mathrm{p}$ & 0,341 & 0,041 & 0,530 & 0,090 & 0,310 \\
\hline & $\mathrm{N}$ & 209 & 209 & 209 & 209 & 209 \\
\hline \multirow{3}{*}{ Kepribadian dasar } & $\mathrm{r}$ & 0,101 & $0,169^{*}$ & $-0,014$ & $0,154^{*}$ & 0,121 \\
\hline & $\mathrm{p}$ & 0,146 & 0,014 & 0,845 & 0,026 & 0,081 \\
\hline & $\mathrm{N}$ & 209 & 209 & 209 & 209 & 209 \\
\hline
\end{tabular}

antara: a) potensi kinerja dan skor persepsi integritas akademik ( $p=0,014$ dan $r=0,169)$; b) potensi kinerja dan skor perilaku integritas akademik ( $p=0,030$ dan $\mathrm{r}=0,150)$; dan c) kemampuan adaptasi dan skor persepsi terhadap integritas akademik teman sesama mahasiswa ( $p=0,031$ dan $r=0,150)$; serta kendala psikologis dan skor perilaku integritas akademik ( $\mathrm{p}=$ 0,049 dan $r=0,137$ ).

Penelitian menemukan adanya hubungan korelasi yang lemah dengan arah korelasi positif antara potensi kinerja dengan tingkat pendidikan mahasiswa. Semakin tinggi tingkat pendidikan mahasiswa, maka potensi kinerjanya juga akan meningkat. Karena tidak dtemukan hubungan korelasi antara potensi kinerja dengan umur, tetapi ditemukan hubungan korelasi antara potensi kinerja dengan tingkat pendidikan, muncul dugaan dan harapan bahwa peningkatan potensi kinerja dapat diintervensi dengan pendidikan. Pengembangan pendidikan integritas akademik diduga dan diharapkan juga dapat meningkatkan potensi kinerja integritas akademik mahasiswa, sehingga secara lebih lanjut, diharapkan perilaku integritas akademiknya juga dapat ditingkatkan. Pengembangan pendidikan integritas akademik diharapkan dapat mempengaruhi sikap terhadap perilaku, norma-norma subjektif dan kontrol perilaku yang dihayati. Khusus untuk kontrol perilaku yang dihayati, interfensi melalui kontrol perilaku integritas akademik pada peraturan akademik dan pengawasan/evaluasi perilaku integritas akademik amat diperlukan.

Berdasar Tabel 2, ditemukan bahwa secara statistik terdapat korelasi lemah dengan arah korelasi negatif antara integritas moral dengan skor persepsi 
integritas akademik ( $p=0,001$ dan $r=-0,220)$. Secara logika, seharusnya semakin tinggi integritas moral, maka skor persepsi integritas akademik makin tinggi pula. Belum ditemukan jawaban tentang hal yang melatar belakangi fakta yang terjadi pada hasil tersebut. Penelitian lebih lanjut diperlukan untuk mengetahui latar belakang hal ini. Pengetahuan adanya kemungkinan pengaruh faktor lingkungan yang lebih besar dapat memberikan kontribusi terhadap pembinaan dan pengembangan integritas mahasiswa. Fakta lain tentang integritas moral pada penelitian ini adalah secara statistik terdapat korelasi lemah antara:

1. Jenis kelamin dan integritas moral $(\mathrm{p}=0,009$ dan $r=0,208)$. Laki-laki memiliki integritas moral yang lebih baik.

2. Tingkat pendidikan ibu dan integritas moral ( $\mathrm{p}$ $=0,036$ dan $r=0,285)$. Semakin tinggi tingkat pendidikan ibu, maka integritas moralnya akan semakin baik pula.

Penelitian menunjukkan bahwa terdapat hubungan korelasi lemah antara keterbukaan pikiran dengan tingkat pendidikan, didapatkan $\mathrm{p}=0,008 \mathrm{dan}$ $r=0,285$ (korelasi lemah dengan arah korelasi yang positif). Semakin tinggi tingkat pendidikan mahasiswa, maka semakin tinggi pula keterbukaan pikiran. Karena tidak ditemukan adanya hubungan korelasi antara keterbukaan pikiran dan umur, muncul dugaan dan harapan bahwa peningkatan integritas akademik dapat diintervensi dengan pendidikan. Pengembangan pendidikan integritas akademik diduga dan diharapkan dapat meningkatkan keterbukaan pikiran mahasiswa terhadap insight integritas akademik. Hergenhahnn ${ }^{11}$ menjelaskan bahwa pembentukan perilaku dapat dilakukan dengan memberikan pengertian atau insight.

Di sisi lain, pada penelitian ini ditemukan bahwa secara statistik terdapat korelasi sangat lemah antara jenis kelamin dengan skor persepsi integritas akademik ( $p=0,017$ dan $r=0,194)$, serta korelasi sangat lemah dengan arah korelasi negatif antara: a) tingkat pendidikan dan skor persepsi integritas akademik ( $\mathrm{p}=0,007$ dan $\mathrm{r}=-0,135)$; dan $\mathrm{b}$ ) tingkat pendidikan dan skor intensi integritas akademik ( $\mathrm{p}$
$=0,048$ dan $r=-0,097)$. Temuan a) dan b) tersebut mengingatkan pada teori protoprofesionalisme dari Hilton dan Slotnick. Hilton dan Slotnick ${ }^{12}$ menyatakan bahwa phronesis (kebijaksanaan praktis) diperoleh hanya setelah periode lama dari pengalaman (dan refleksi atas pengalaman) yang terjadi dalam perkembangan pengetahuan profesional dan keterampilan dasar, suatu periode yang disebut sebagai 'proto-profesionalisme'. Pengaruh proto-profesionalisme penting bagi perkembangan moral, psikososial dan penilaian reflektif. Dengan demikian suatu kurikulum yang mengembangkan meta-keterampilan akan mendorong akuisisi dan pemeliharaan profesionalisme. Kondisi lingkungan yang merugikan dalam kurikulum yang tersembunyi dapat memiliki efek attritional yang kuat.

\section{KESIMPULAN}

Suatu tantangan besar bagi institusi untuk membentuk supporting system yang menunjang pembentukan dan pengembangan integritas akademik mahasiswa. Sebelum membentuk dan membangun integritas akademik mahasiswa, seluruh karyawan, staf pengajar maupun sistemnya harus menunjukkan integritas dan perilaku profesional. Role model merupakan salah satu kata kunci.

\section{UCAPAN TERIMA KASIH}

Ucapan terima kasih disampaikan pada Lisa Musharyanti, MMedEd yang telah mengizinkan penggunaan kuesioner integritas akademik edisi Indonesia, dr. Ria Maria Theresa, SpKJ yang telah terlibat secara mendalam pada analisa MMPI-2 dan dr Runinda Pradnyamita yang telah membantu proses pengambilan data dan memberikan masukan untuk kelancaran penelitian ini.

\section{KONFLIK KEPENTINGAN}

Mahasiswa yang menjadi subjek dalam penelitian ini merupakan mahasiwa tahap akademik di institusi tempat peneliti bekerja.

\section{DAFTAR PUSTAKA}

1. Passi V, Doug M, Peill Ed, Thistlethwaite J, Johnson N. Developing medical professionalism in 
future doctors: a systematic review. Int. J. Medical Education. 2010; 1:19-29.

2. Petersdorf RG. A matter of Integrity. Ac Med. 1989; 64: 119-23

3. Swick, H. Toward A Normative Definition of Medical Professionalism. Ac Med. 2000;75(6):612 16.

4. Van Luijk SJ. editors. Professional behaviour: Teaching, Assessing and Coaching Students. Final report. Project Team Consilium Abeundi. Maastricht: Universitaire Pers Maastricht; 2005.

5. General Medical Council \& Medical Schools Council. Medical students:

6. Professional behaviour and fitness to practise, Guidance from the GMC and the MSC. 2007. [cited 2011 Mar 3] Available from: www.gmc-uk.org/ education/.../professional_behaviour.asp

7. The Center of Academic Integrity. The Fundamental Values of Academic Integrity. Duke University. 1999. [cited 2011 Oct 23] Available from: www. academicintegrity. org/fundamental_values.../FVProject. $p d f$
8. Maslim R. Manual Pelatihan MMPI-2 Indonesia. Jakarta: Indonesian Center for Mental Health Training and Research (ICMTR); 2005.

9. Musharyanti L. Persepsi dan Perilaku Mahasiswa Keperawatan tentang Integritas Akademik di Program Studi Ilmu Keperawatan Fakultas Kedokteran Universitas Gadjah Mada [Tesis]. Yogyakarta (Indonesia) Universitas Gadjah Mada; 2010.

10. Butcher JN, Graham JR. Adolescent \& Elderly Adults. In: Greene RL. The MMPI-2 an interpretive Manual, second ed, chapter. 10, Allyn \& Bacon A Pearson Educational Company; 1989.

11. Syamsuddin L, Syauki. Profil MMPI dan Indeks Prestasi (IP) Mahasiswa Kedokteran. Jurnal Medika Nusan-tara. 2006;27:11-4.

12. Walgito B. Pengantar Psikologi Umum. Yogyakarta: Penerbit Andi; 2010.

13. Hilton SR, Slotnick HB. Proto-professionalism: How professionalisation occurs across the continuum of medical education. Med Educ. 2005;39(1):58-65. 